\title{
Study in Financing Difficulties and Strategies of China's Small and
}

\author{
Medium Enterprises
}

\author{
Xuefei Hong \\ Shandong Institute Of Commerce And Technology, Jinan, China
}

\begin{abstract}
Keywords: Small and medium enterprise, Financing difficulties, Countermeasures, Financing channel
\end{abstract}

\begin{abstract}
The rapid development of small and medium enterprises has become an important force in driving China's economic growth and absorbing social employment which plays an irreplaceable fiction. However, the time of the development and establishment of Chinese small and medium enterprises is relatively short and thus they still have many problems and difficulties, especially in terms of financing. The relatively low credibility and fewer fixed assets all made those SMEs have more difficulties in financing which undoubtedly become an important reason in limiting their development. Facing the financing difficulties reality, our SMEs need to take effective countermeasures to realize a further development and give full play of promoting the development of national economy.
\end{abstract}

\section{Introduction}

Small and medium enterprises have many functions like improve the employment rate, increase local revenue, improve people's living conditions, promote the economic development of stockholders and promote industrial restructuring, etc. but there exists many problems from both internal management and external management, coupled with low credibility and high costs of financing and resulting financing difficulties, which seriously limited the development of them. Facing those problems, only by taking effective countermeasures, could we solve financing problems of small and medium enterprises.

\section{Financing Actualities of SMEs}

In the development process of our economy, the number of small and medium enterprises is more than ten million, accounting for more than 95\% of the total number of Chinese enterprises, created a great number of employment opportunities for China's economic development and fully stimulating the country's economic recovery. However, in the process of the development of SMEs, they are still facing many problems, especially in terms of financing, existing certain difficulties. Firstly, the internal financing is the main financing channel of our SMEs with lower financing risks and financing costs but mere rely on their own fund could not enlarge the business size what in turn limited the development of enterprises. Secondly, the external financing channel of SMEs is mainly through bank loans and most of the fund comes from bank loans. Moreover, the direct financing channels of SMEs is very narrow, and the proportion of financing by the direct financing channels is quite small. Finally, due to the SMEs' smaller size, lower level of management and weak assets resist ability and other reasons, their financing channels are restricted in the capital markets and banks. If the internal financing could not meet the needs of enterprise funds, the SMEs could only 
achieve financing through efficient commercial credit, private loans, underground banks and other non-formal channels. Although the financing costs of these non-formal channels are higher, they could fulfill enterprises' fund needs, and its financing procedure are relatively simple but bring many subsequent risks.

\section{Financing Difficulties of SMEs}

The Widespread of Information Asymmetry. The so-called information asymmetry is means one side holds the relevant information and the other lack of relevant information. The information asymmetry distribution between the two sides of transaction enables the side have superiority information do damages to other side. The first kind is the information asymmetry between banks and enterprises which results the banks could not accurately understand the real financial situation of enterprises or could not grasp their repayment capacities and exacerbated its financing difficulties in the end. The next information asymmetry is between the security agencies and enterprises. When the small and medium enterprises cannot get loans from banks, the loan guarantee agency as the second resources will directly influenced enterprises' financing situation. But in reality, the SMEs generally reflects that the guarantee agencies set high thresholds and charge exorbitant warrant costs. For the purpose of profit, the warrant costs charged by the current guarantee agencies are even more than $50 \%$ of the floating upper limit set by the state which is the result of "adverse selection" and "moral hazard" caused by the information asymmetry.

Low Credibility of SMEs. Although the SMEs have occupied certain portion in our country's economic market, their business scales are small and less corresponding number of employees, thus exists a large gap compared with large enterprises in the market development, together with their late starting and low credibility in the market which lead financing problems and reducing its financing efficiencies.

Heavily in Debt and Insufficient Equity Financing of SMEs. Because the development and emergence of SMEs in our country is relatively short, and their system and institutions are incomplete. In the financing process of SMEs, they generally using the way of bond financing, that is to say financing from civil organizations, credit unions and banks made them indebtedness which will seriously affect their innovative development. The investment mechanism of SMEs resulting obvious insufficiency of its equity financing. The improvement of the system and self-regulatory mechanism greatly reduced the financing difficulties.

SMEs Lack of Government Support. The development of SMEs is an important measure to improve the development of China's economy and it is necessary to pay attention to their development and provide favorable support. In other country's SMEs development process, the government will provide some supports by establishing a series of policy-oriented financial institutions. However, in our nation, the financial institutions established by the government are insufficient and it is difficult to give some support to their development, resulting its backward financing capacity.

Lack of Financing Guarantee System of SMEs. At present, many aspects of China's financial institutions are not mature enough, and most of the financial policies and systems are mainly for state-owned enterprises, so the guarantee system are mainly for large enterprises while for SMEs, it is quite insufficient and leading many problems like financing difficulties and others. Therefore, it is necessary to improve our country's guarantee system.

\section{The Financing Strategies of SMEs in Our Country}


In order to improvement the financing situations of existing small and medium enterprises, we must make some comprehensively improvement to increase their financing efficiencies, enhancing the operation efficiencies of enterprises and stimulating their development potentials in the end.

Comprehensively Enhance Their Economic Forces. Credibility is the core of enterprise management and a better credit is a preconditions for the common survival and further development and lack of credit is the most fundamental reason of small and medium enterprises' financing difficulties. To obtain bank loans, SMEs must pay attention to its credit and repay the loan on time, only by this way could the banks loan to other small and medium enterprises which could continue to develop, thus they should constantly improve their own qualities.

Increase the Government's Support Forces for SMEs, Improve Enterprise Financing. In the process of our country's economic development, the government is an important force to regulating the development of economy and played a function of macro-control. Therefore, in order to expand the fully development and financing channel pf SMEs, the government should strengthen its focus, enhancing its support efforts and establish a certain effective financing system to fully improve their economy development. The development of SMEs need the strong support of local government, one important one is the tax concessions. In our country's economic development zones, the local government have developed related tax concessions to attract the invest of local companies and non-local companies, like relief the tax income for the previous three years, half relief of the tax income after three years or payed by the local financial department. Under the condition do not affecting the fair competition, the government could give a certain percentage of tax concessions to some qualified SMEs, give more preferential tax policies and innovation subsidies to those better growth potential, high-tech and high-paying technology SMEs.

Establish a Sound Risk System. The risk awareness is very important for small and medium enterprises. Due to the small size of the company, unstable development and management, the SMEs could not bear any serious risks, therefore, they need the risk preparedness awareness. In any transactions, it is necessary to evaluating the trade financing risks and scientifically control the risks within a certain range by change the direction of development or the usage of differ methods. They should regarded the risk costs as an indicator of the financial system, through that could they obtain an effective management and control of trade risks associated with daily operation. In addition, they should also strengthen the prevention of risks, detail investing the conditions of financial institutions to enhance the communication between enterprises and financial institutions and further avoid various possible risks in the process of trade financing.

Explore Existing Financing Channels---Internet Banking. In the 2015 government work report, Premier Li pointed out that we should ahead with financial reform to better serve the real economy. We will encourage qualified private investors to establish, in accordance with the law, small and medium-sized banks and other financial institutions; there will be no quota imposed on them and approval will be granted as long as all required conditions are met. The introduction of relevant government policies provide a broad development space and have a significant impact on the financing of small and medium enterprises especially small micro-enterprise, the innovation of business model, technological innovation and other activities. The continuous improvement of the equity trading center and multi-level financing system: the financing environment of SMEs gradually relaxed, the strong momentum of the development of internet finance, the continuous opening up of government policies to private assets. With the help of the internet platform and big data resources, the small micro-finance rapidly developed and Alibaba is the most representative "grassroots finance" and its rapid growth situation directly "scared" the bank. According to reports, the Ali finance "Legion" has already embraced Ali micro-finance loan, security companies, 
factoring companies Yu' ebao and other financial formats. The Ali micro-finance loan for example, the small and micro-enterprise clients it serviced is more than 520,000 and loans more than 130 billion yuan. In the end of September 2013, the funds size of Yu' ebao has reached 56.7 billion yuan.

Develop of Asset Pawn Financing--- the Function of “Green Channel” Pawn financing. Pawn is a main channel of folk financing and plays an important role in adjust the remaining, promote the circulation, maintaining social stability. At present, pawn refers to a special financial company in transfer of possession providing temporary pledge loans for non-state-owned small and medium enterprises and individuals, it is an effective complement financing channels to our small and medium enterprises. One reason is it meets the urgent short-term fund need of small and medium enterprises timely. Pawn with its convenient, flexible features playing an increasingly important role in social services, helping small and medium enterprises seizing development opportunities, solving the problem of inadequate fund for the production and other problems. Then, it reduce the financing cost and financing risk for SMEs. The specification financing procedure of pawn effectively eliminates many concerns of SMEs. Comparing with folk direct financing, the pawn have many advantages like low costs, security guarantee the costs of pawn is low, avoiding the suffering of owe money and effectively eliminating various disputes and the proliferation of civil user.

\section{Conclusion}

The small and medium enterprises in China is in a critical period and experiencing a new round of development, and the sufficient fund will enable promoting its rapid development, on the contrary they will face the survival crisis. Therefore, the financing problems of SMEs in the post-financial crisis era seems being more urgent and prominent. The solving of the financing problems of SMEs is an indispensable system concern with enterprises, financial institutions, government and many other aspects, and can be truly solved by coordinated with each other and do efforts together. By solving of the financing difficulties, SMEs could get a healthy and sufficient development, our national economy could keep healthy and stable development and realize the harmony of society.

\section{References:}

[1] J.H.Hu, J.X.Hu. A Study of the Financing Effective of SMEs. Chinese Business, 2011 (12). (In Chinese)

[2] X.Y. Zheng. Analysis of Financing Problems of SMEs. Modern Business, 2011 (23). (In Chinese)

[3] Y.Z. Li. Research of the Improvement of the Financing System of Our Nation's SMEs. Beijing, 2010 (4). (In Chinese)

[4] M.H. Research of the Private Finance Support and Innovation of SMEs. Theory Monthly, 2011 (2). (In Chinese) 